\title{
Mitotic chromosome condensation in the rDNA requires TRF4 and DNA topoisomerase $I$ in Saccharomyces cerevisiae
}

\author{
Irene B. Castaño, ${ }^{1}$ Pius M. Brzoska, Ben U. Sadoff, Hongying Chen, and Michael F. Christman ${ }^{1,2}$ \\ Department of Radiation Oncology, University of California, San Francisco, California 94143 USA
}

\begin{abstract}
DNA topoisomerase $I$ (topo I) is known to participate in the process of DNA replication, but is not essential in Saccharomyces cerevisiae. The TRF4 gene is also nonessential and was identified in a screen for mutations that are inviable in combination with a top1 null mutation. Here we report the surprising finding that a top1 trf4-ts double mutant is defective in the mitotic events of chromosome condensation, spindle elongation, and nuclear segregation, but not in DNA replication. Direct examination of rDNA-containing mitotic chromosomes demonstrates that a top 1 trf4-ts mutant fails both to establish and to maintain chromosome condensation in the rDNA at mitosis. We show that the Trf4p associates physically with both Smc1p and Smc2p, the $S$. cerevisiae homologs of Xenopus proteins that are required for mitotic chromosome condensation in vitro. The defect in the top 1 trf4-ts mutant is sensed by the MAD1-dependent spindle assembly checkpoint but not by the RAD9-dependent DNA damage checkpoint, further supporting the notion that chromosome structure influences spindle assembly. These data indicate that TOP1 (encoding topo I) and TRF4 participate in overlapping or dependent steps in mitotic chromosome condensation and serve to define a previously unrecognized biological function of topo $I$.
\end{abstract}

[Key Words: DNA topoisomerase; chromosome condensation; mitosis; nuclear division; checkpoint]

Received July 29, 1996; revised version accepted August 26, 1996.

Chromosomes are involved in dynamic cellular processes such as DNA replication, transcription, chromatin assembly, mitotic condensation, and genetic recombination that can lead to the formation of local domains of torsional stress (for review, see Wang and Lynch 1993). In Saccharomyces cerevisiae, DNA topoisomerases I and II (topo I and II) appear to act together during DNA replication as a swivel to relieve torsional stress at the replication fork. When both topo I and II are inactivated, DNA replication stops rapidly (Brill et al. 1987), with elongation of new DNA chains continuing for only a few thousand nucleotides (Kim and Wang 1989). Transcription can also lead to the formation of locally supercoiled domains in DNA. In the twin domain model (Liu and Wang 1987), movement of a transcription complex along the helical backbone generates positive supercoils ahead of the complex and negative supercoils behind the complex. In $S$. cerevisiae, topo I and II function together to facilitate rRNA transcription and, to a lesser extent, mRNA transcription (Brill et al. 1987).

Despite the considerable evidence for the involvement

\footnotetext{
${ }^{1}$ Present address: Department of Microbiology, Box 441, Jordan Hall, University of Virginia School of Medicine, Charlottesville, Virginia 22908 USA. E-MAIL mfc3f@virginia.edu.

${ }^{2}$ Corresponding author.
}

of topo I in both DNA replication and transcription, topo I is not essential in either $S$. cerevisiae or Schizosaccharomyces pombe. Null mutations in TOP1, the gene encoding the only type I DNA topoisomerase activity detectable in crude extracts, cause only modest growth defects (Thrash et al. 1984; Uemura and Yanagida 1984; Thrash et al. 1985). Furthermore, the overall rates of both DNA and RNA synthesis are normal in top1 mutants (Brill et al. 1987), supporting the suggestion that topo II activity can substitute for topo I activity in these crucial processes (Uemura and Yanagida 1984; Goto and Wang 1985; Brill et al. 1987). In both S. cerevisiae and $S$. pombe conditional top2 mutations exacerbate the growth defect of top1 cells (Goto and Wang 1985; Uemura et al. 1987a). This demonstrates that some of the functions of type I and type II topoisomerases overlap. It remains unclear, however, whether topo I has additional functions distinct from those of topo II.

To investigate further the in vivo functions of topo I, we perfomed a genetic screen to identify mutations affecting gene products that perform overlapping or dependent functions with topo I and, thereby, to elucidate further which processes in the cell require topo I (Sadoff et al. 1995). We have identified four complementation groups of mutants with this phenotype called $T R F$, for 
DNA Topoisomerase I-Related Function (Sadoff et al. 1995; Žhu et al. 1995; Castaño et al. 1996). The predicted Trf4 protein shares homology with the amino-terminus of Toplp (Sadoff et al. 1995) and is a member of a novel gene family that is evolutionarily conserved (Castaño et al. 1996). Null mutations in trf4 display only a slight growth defect but are completely inviable in combination with a top1 null mutation despite having a normal level of active topo II (Sadoff et al. 1995). Thus, we have investigated the reason for the inviability of the top $1 \operatorname{trf} 4$ double mutant.

Whereas topo II is known to be required for mitotic chromosome condensation both in vitro (Adachi et al. 1991; Hirano and Mitchison 1993) and in vivo (Uemura et al. 1987b) and for separating intertwined, replicated chromosomes at the time of mitosis (DiNardo et al. 1984; Holm et al. 1985), there was little evidence to suggest the involvement of a type I DNA topoisomerase in mitotic events. An evolutionarily conserved class of proteins required for mitotic chromosome condensation have been identified using a combination of a Xenopus cell-free system (Hirano and Mitchison 1994) and fungal genetics (Saka et al. 1994; Strunnikov et al. 1993, 1995). The Xenopus XCAP-C and XCAP-E proteins are part of a protein complex required for condensation in vitro (Hirano and Mitchison 1994) and are related to S. cerevisiae Smc1 and Smc2 proteins, respectively (Strunnikov et al. 1993, 1995). The Smclp and Smc2p proteins are also associated with each other in vivo (Strunnikov et al. 1995). Whereas it had been thought that $S$. cerevisiae chromosomes may be too small to necessitate significant condensation at mitosis to facilitate segregation, recent studies using fluorescently labeled probes demonstrate that condensation does occur in yeast (Guacci et al. 1994; Saka et al. 1994) and that the genes required for condensation in yeast are related to those required for condensation in vertebrates (Hirano and Mitchison 1994; Hirano 1995).

We report here the unexpected result that a top 1 trf4-ts double mutant is defective in the mitotic events of chromosome condensation, spindle elongation and nuclear segregation, but not in DNA replication at the restrictive temperature. Furthermore, we show that genetic and physical interactions are observed between the TRF4 and the $S M C$ genes and proteins, which are the $S$. cerevisiae homologs of Xenopus proteins required for chromosome condensation in vitro. These data indicate that TOP1 and TRF4 participate in overlapping or dependent steps in mitotic chromosome condensation and serve to define a previously unrecognized biological function of topo I.

\section{Results}

\section{A top1 trf4-ts double mutant dies at the time of mitosis}

A TRF4 allele was identified in a screen for mutants with TOP1 (encoding topo I)-requiring mutations. To determine the cause of the inviability of the top 1 trf 4 double mutant, we isolated an allele of trf 4 that was tempera- ture sensitive for growth in a top1 genetic background and replaced the wild-type TRF4 allele with the $t s$ allele to generate a top1 trf4-ts double mutant (see Materials and Methods). The trf4-ts allele is recessive for inviability in combination with top 1 and, therefore, is likely to be a loss-of-function mutation. To determine whether the common function performed by TOP1-TRF4 is required at a specific time in the cell cycle, we synchronized cultures of the top 1 trf4-ts mutant in the $G_{1}$ phase of the cell cycle using $\alpha$-factor at a permissive temperature $\left(24^{\circ} \mathrm{C}\right)$, and released cells from the block in liquid culture by $\alpha$-factor withdrawal at either $24^{\circ} \mathrm{C}$ or at a restrictive temperature $\left(37^{\circ} \mathrm{C}\right)$ while monitoring both cell number and cell viability following release. The $24^{\circ} \mathrm{C}$ culture displayed the expected constant cell number and number of colony-forming units (cfu) for $1.5 \mathrm{hr}$, followed by an approximately twofold increase in cell number and in the number of colony forming units, resulting from cell division, between 1.5 and $2.5 \mathrm{hr}$ after release (Fig. 1A). The $37^{\circ} \mathrm{C}$ culture also maintained the original cell number and number of cfu for $1.5 \mathrm{hr}$ after release. However, whereas cell division occurred at $37^{\circ} \mathrm{C}$ between 1.5 and $2.5 \mathrm{hr}$, just as it had at $24^{\circ} \mathrm{C}$, the number of cfu (viable cells) failed to increase at all upon cell division and subsequently began to decrease (Fig. 1A).

When the top 1 trf4-ts mutant was shifted to the restrictive temperature without the removal of $\alpha$-factor so that cells remained in $G_{1}$, very little loss of viability was observed. Figure 1B shows the ratio of cfu (viable cells) to cell number on the $y$-axis for cultures of the top1 trf4-ts mutant that were synchronized in $G_{1}$ with $\alpha$-factor as described above and then either released from the block at $24^{\circ} \mathrm{C}$ or $37^{\circ} \mathrm{C}$ or held at $37^{\circ} \mathrm{C}$ in the presence of $\alpha$-factor. The $37^{\circ} \mathrm{C}$ culture that remains in $G_{1}$ because of the continued presence of $\alpha$-factor shows approximately fourfold greater viability (cfu/cell) than the culture that was allowed to proceed through mitosis. These data indicate that the top1 trf4-ts mutant grown at the restrictive temperature undergoes a cell division that results in inviable progeny in the first cell cycle following temperature shift and, furthermore, that top1 trf4-ts cells maintained in $G_{1}$ for the same time period at the restrictive temperature largely remain viable.

\section{Spindle elongation and nuclear division are defective in the topl trf4-ts mutant}

Kinetic analysis of DNA content by flow cytometry following $\alpha$-factor release shows that wild-type and top1 trf4-ts cultures complete DNA synthesis at the same rate at the restrictive temperature of $37^{\circ} \mathrm{C}$ (Fig. 2A). In addition, the rate of DNA synthesis is the same at both $24^{\circ} \mathrm{C}$ and $37^{\circ} \mathrm{C}$ for the top 1 trf4-ts culture (not shown). This indicates that there is no gross failure to complete DNA synthesis in the top1 trf4-ts mutant at the restrictive temperature. Whereas DNA synthesis is completed at a wild-type rate in the top1 trf4-ts mutant, 4'6-diamidino-2-phenylindole (DAPI) staining revealed several defects in nuclear division by $1.5 \mathrm{hr}$ after $\alpha$-factor release. The $37^{\circ} \mathrm{C}$ culture displayed many cells in which the nu- 
A

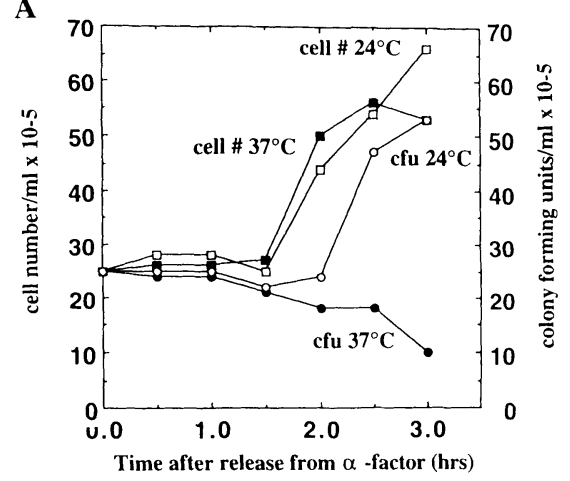

B

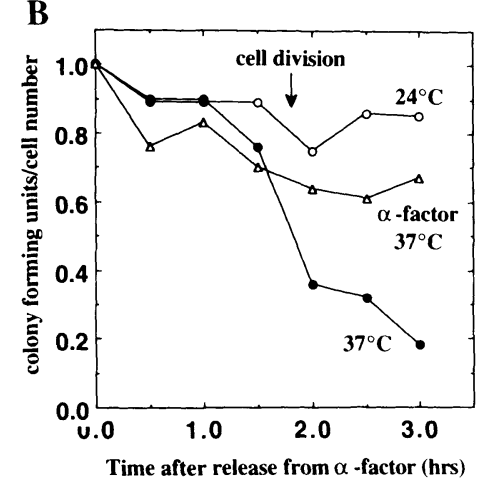

A

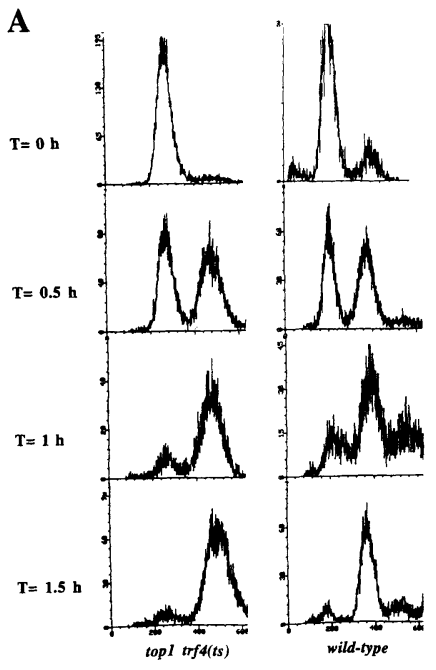

B

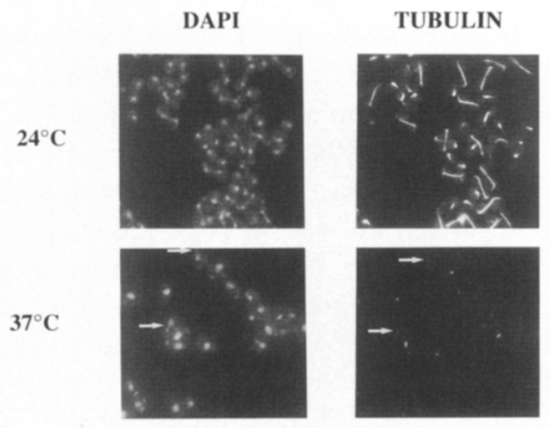

Figure 1. A top1 trf4-ts mutant dies at the time of mitosis. $\langle A|$ Cells of strain CY950 (MATa top1 trf4-ts) were grown to logarithmic phase in YPD at $24^{\circ} \mathrm{C}$ and synchronized in the $G_{1}$ phase with $\alpha$-factor. After 1.5 generations cells were harvested, washed, and resuspended in fresh medium. One half of the culture was further incubated at $24^{\circ} \mathrm{C}$ and the other half at $37^{\circ} \mathrm{C}$. Samples were withdrawn every $30 \mathrm{~min}$, diluted in sterile water and appropriate dilutions were plated on YPD plates at $24^{\circ} \mathrm{C}$ to determine the number of colony forming units (cfu). (B) Cells were treated as above except that $\alpha$-factor was not removed from one culture at $37^{\circ} \mathrm{C}$. The number of cells was determined by counting each sample in a hemocytometer under a light microscope.

cleus appears unevenly divided between the mother and daughter cells upon spindle elongation, indicative of aberrant nuclear division (see arrows in Fig. 2B). Cells with unevenly divided nuclei constitute $37 \%$ of those undergoing nuclear division at the restrictive temperature $(\mathrm{Ta}$ ble 1). Unevenly divided nuclei were not observed at the permissive temperature. In addition, after $1.5 \mathrm{hr}$ at $37^{\circ} \mathrm{C}$, $36 \%$ of top 1 trf4-ts cells appeared to have failed to position the nucleus in the bud neck, whereas none of the cells at $24^{\circ} \mathrm{C}$ failed to (Table 1). Anucleate $(10 \%$ at $2 \mathrm{hr})$ and binucleate cells $(7 \%$ at $2 \mathrm{hr}$ ) were also observed at the restrictive but not permissive temperatures. Consistent with the results obtained using synchronized cultures, the terminal-arrest morphology of asynchronous cultures of the top 1 trf4-ts mutant at $37^{\circ} \mathrm{C}$ included $28 \%$ large-budded cells, $10 \%$ small-budded cells and $62 \%$ unbudded cells $(n=113)$, indicating that a uniform cellcycle arrest does not result from the loss of TOP1-TRF4 function, but that many cells proceed through a defective mitosis.
Figure 2. DNA content, nuclear and spindle morphology in the top1 trf4-ts mutant. (A) DNA content of the top1 trf4-ts mutant and an isogenic wild-type parent strain at $0.5 \mathrm{hr}$ intervals following synchronization with $\alpha$-factor at $24^{\circ} \mathrm{C}$ and release at $37^{\circ} \mathrm{C} .(B)$ Nuclear and spindle morphology of cells $1.5 \mathrm{hr}$ after release from the $\alpha$-factor block at $24^{\circ} \mathrm{C}$ or $37^{\circ} \mathrm{C}$. Cells were fixed and stained with DAPI to visualize DNA and with antitubulin antibody to reveal microtubules. Small arrows denote cells showing unevenly or incompletely divided nuclei that have anaphase spindles. Neither top 1 nor trf 4 single mutants or the wild-type parent strain show aberrant spindles or nuclear morphology at $37^{\circ} \mathrm{C}$.

The synchronous cultures described above were also examined for spindle morphology $1.5 \mathrm{hr}$ after release from the $\alpha$-factor block. Examination of the mitotic spindle by indirect immunofluorescence using an antitubulin antibody shows that the $24^{\circ} \mathrm{C}$ culture consists primarily of cells with long, anaphase spindles, whereas the $37^{\circ} \mathrm{C}$ culture contains few cells with anaphase spindles and primarily cells with short bipolar spindles (Fig. 2B and Table 2). Examination of the $37^{\circ} \mathrm{C}$ culture up to $3 \mathrm{hr}$ after release showed that few anaphase spindles are ever established (Table 2). The anaphase spindles that were observed at $37^{\circ} \mathrm{C}$ appeared much thinner and stained more faintly than normal spindles. Neither top 1 nor trf4 single mutants, nor our wild-type parent strain showed spindle defects at $37^{\circ} \mathrm{C}$. Thus, top1 trf4-ts cells are able to complete DNA synthesis and establish a short bipolar 
Table 1. Nuclear morphology and position in topl trf4-ts

\begin{tabular}{lcccc}
\hline \multirow{2}{*}{$\begin{array}{l}\text { Time } \\
\text { after } \\
\text { release }\end{array}$} & $\begin{array}{c}\text { Small- and medium-budded } \\
\text { budneck in }(\%)\end{array}$ & $\begin{array}{c}\text { nucleus not in } \\
\text { budneck }(\%)\end{array}$ & $\begin{array}{l}\text { Large-budded } \\
\text { (with two } \\
\text { distinct nuclear } \\
\text { masses) }(\%)\end{array}$ \\
\hline $24^{\circ} \mathrm{C}$ & & & & \\
$1 \mathrm{hr}$ & $70(0 \%)^{\mathrm{a}}$ & 15 & 5 & $n=59$ \\
$1.5 \mathrm{hr}$ & $23(0 \%)^{\mathrm{a}}$ & 0 & 48 & $n=63$ \\
$37^{\circ} \mathrm{C}$ & & & & \\
$1 \mathrm{hr}$ & $34(20 \%)^{\mathrm{a}}$ & 32 & 0 & $n=105$ \\
$1.5 \mathrm{hr}$ & $39(37 \%)^{\mathrm{a}}$ & 36 & $<1$ & $n=123$ \\
\hline
\end{tabular}

Cells from the experiment shown in Fig. 2 were counted under a fluorescence microscope ( $n$, number of cells counted).

${ }^{\text {a }}$ Percent that contained a nucleus that was unevenly distributed between mother and daughter cells.

spindle at the restrictive temperature, but subsequently fail to elongate the mitotic spindle properly and complete nuclear division.

trf4 and top 1 mutants are defective in centromere-mediated plasmid segregation

Plasmid loss assays have been used to distinguish between defects in DNA replication and segregation (Strunnikov et al. 1993). Mutants defective in plasmid replication are expected to display increased loss rates for both centromere and $2 \mu$ plasmids, whereas mutants with a centromere-mediated segregation defect are expected to display a high loss rate of $C E N$ plasmids only. The mitotic stability of two different plasmids marked with URA3 and either $C E N$ or $2 \mu$ sequences was measured by determining the percentage of cells in a culture that retained the plasmid under selection (Strunnikov et al. 1993). A trf4 single deletion mutant displayed a 10fold higher rate of centromere plasmid loss than an oth-

Table 2. Spindle morphology in topl trf4-ts

\begin{tabular}{ccccc}
\hline $\begin{array}{l}\text { Time } \\
(\mathrm{h})\end{array}$ & $\begin{array}{l}\text { Long } \\
\text { anaphase } \\
\text { spindles }\end{array}$ & $\begin{array}{l}\text { Short } \\
\text { bipolar } \\
\text { spindles }\end{array}$ & $\begin{array}{l}G_{1} \text {-like } \\
\text { asters }\end{array}$ & \\
\hline $24^{\circ} \mathrm{C}$ & & & & \\
0 & 0 & 0 & 100 & $(n=133)$ \\
0.5 & 0 & 8 & 92 & $(n=135)$ \\
1 & 13 & 43 & 43 & $(n=106)$ \\
1.5 & 62 & 23 & 15 & $(n=127)$ \\
2 & 6 & 13 & 82 & $(n=120)$ \\
3 & 22 & 48 & 30 & $(n=28)$ \\
$37^{\circ} \mathrm{C}$ & & & & \\
0 & 0 & 0 & 100 & $(n=133)$ \\
0.5 & 0 & 1 & 99 & $(n=117)$ \\
1 & 5 & 61 & 33 & $(n=107)$ \\
1.5 & 3 & 80 & 17 & $(n=115)$ \\
2 & 6 & 46 & 47 & $(n=79)$ \\
3 & 7 & 40 & 47 & $(n=15)$ \\
\hline$T$
\end{tabular}

$\mathrm{T}=0$ is defined as the time immediately after $\alpha$-factor release; $n$, number of cells counted.
A

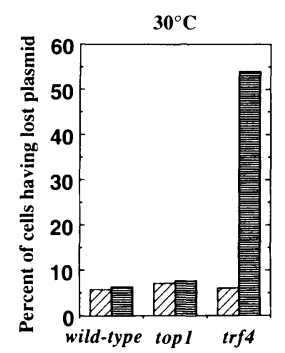

B

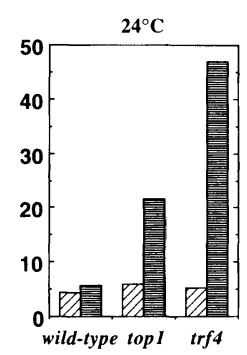

Figure 3. trf4 and top1 null mutants display an increased rate of CEN plasmid loss. Cultures of wild-type (CY184), $\Delta$ top1$7::$ LEU2 (CY185) and $\Delta$ tfr4-101::HIS3 (CY855) strains were transformed with either pYEp24 $(2 \mu)$ (hatched bars) or pRS316 $(C E N)$ (gray bars) plasmids to $\mathrm{Ura}^{+}$. Cells were grown to exponential phase $\left(\mathrm{A}_{600}=1.5\right)$ in SC-Ura medium at $(A) 30^{\circ} \mathrm{C}$ or $(B)$ at $24^{\circ} \mathrm{C}$, and aliquots were then diluted in sterile water and plated on medium containing uracil. Replica prints were made to SC-Ura plates to calculate the percentage of colonies that had lost the plasmid.

erwise isogenic wild-type strain at $30^{\circ} \mathrm{C}$ (Fig. 3A). However, the mutant did not show an increased loss rate of a $2 \mu$ plasmid, indicating that trf4 single mutants are defective in centromere-mediated plasmid segregation and not in plasmid replication. A top1 single mutant did not show an increased loss rate of either centromere or $2 \mu$ plasmids at $30^{\circ} \mathrm{C}$, but at $24^{\circ} \mathrm{C}$ a threefold increased rate of $C E N$ plasmid loss is observed, whereas no change in loss rate is observed in an isogenic wild-type strain at $24^{\circ} \mathrm{C}$ (Fig. 3B). This suggests that top 1 and trf4 mutants are not defective in plasmid DNA replication but are defective in centromere-mediated plasmid segregation.

\section{Genetic and physical interaction between TRF4 and SMCs}

Several of the phenotypes of the top1 trf4-ts mutant, such as failure to elongate the mitotic spindle, the presence of unevenly divided nuclei and an increased rate of centromere plasmid loss, are shared by mutants defective in SMC1 (Strunnikov et al. 1993) or SMC2 (Strunnikov et al. 1995). The SMC1 and SMC2 genes are the $S$. cerevisiae homologs of Xenopus XCAP-C and XCAP-E, proteins required for mitotic chromosome condensation in vitro (Hirano and Mitchison 1994). To determine whether TRF4 might also function in chromosome condensation, we attempted to make double mutants by crossing a strain containing a trf4 null mutation (CY855) and a strain carrying an smc1-2 point mutation (3aAS273; see Materials and Methods). In 46 tetrads dissected from this cross, we recovered 43 (of the expected 46) $\mathrm{SMC1}^{+} \mathrm{TRF}^{+}$meiotic segregants, $24 \mathrm{SMC1}^{+}$trf4segregants, $33 \mathrm{smc1}^{-} \mathrm{TRF4}^{+}$segregants but no $\mathrm{smc1}{ }^{-}$ $\operatorname{trf} 4^{-}$segregants after 3 days at $24^{\circ} \mathrm{C}$ (Table 3 ). However, after 6 days at $24^{\circ} \mathrm{C}$ seven apparent smc1-2 $\operatorname{trf} 4^{-}$segregants were recovered as pinpoint colonies. This indicates that smc1-2 trf4 double mutants have a severe 
Table 3. Genetic interaction between smcl-2 and trf4

\begin{tabular}{|c|c|c|c|}
\hline Genotype recovered & $\begin{array}{l}\text { Number } \\
\text { of } \\
\text { spores } \\
\text { after } \\
3 \text { days }\end{array}$ & $\begin{array}{l}\text { Number of } \\
\text { pinpoint } \\
\text { colonies } \\
\text { after } \\
6 \text { days }\end{array}$ & $\begin{array}{l}\text { Total } \\
\text { expected }\end{array}$ \\
\hline SMC1 TRF4 & 43 & 0 & 46 \\
\hline smc1-2::LEU2 TRF4 & 33 & 0 & 46 \\
\hline SMC1 trf4-101::HIS3 & 24 & 0 & 46 \\
\hline smc1-2::LEU2 trf4-101::HIS3 & 0 & 7 & 46 \\
\hline
\end{tabular}

Strain CY890 (MATa $\Delta$ trf4-101::HIS3) was crossed with strain 3aAS273 (MAT $\alpha$ smc1-2::LEU2) at $24^{\circ} \mathrm{C}$ and sporulated. Tetrads were dissected on YPD plates and incubated at $24^{\circ} \mathrm{C}$ for 6 days. After colonies had grown, the plates were replica-printed to SChis or SC-leu plates to identify single and double mutants. All of the double mutants formed were very tiny colonies (pinpoint colonies) at $24^{\circ} \mathrm{C}$.

growth defect relative to either single mutant. In contrast, trf4 smc2-6 double mutants were readily recovered and did not show a synthetic growth defect (not shown).

The XCAP-E protein is part of a protein complex required for mitotic chromosome condensation in vitro (Hirano and Mitchison 1994). The S. cerevisiae homolog, Smc2p, is also required for mitotic chromosome condensation and is physically associated with Smclp (Strunnikov et al. 1995). Therefore, we sought to determine whether Smclp, Smc2p, and Trf4p were part of the same protein complex using coimmunoprecipitation. The Smc proteins are present in very low abundance and their interaction has only been detected upon overexpression (Strunnikov et al. 1995). Similarly, it was necessary to overexpress Trf4-PYp to detect it by Western blotting. Therefore, to test for interaction a $2 \mu$ plasmid carrying either SMC1 epitope tagged with the MYC epitope or $S M C 2$ epitope tagged with the HA epitope (Strunnikov et

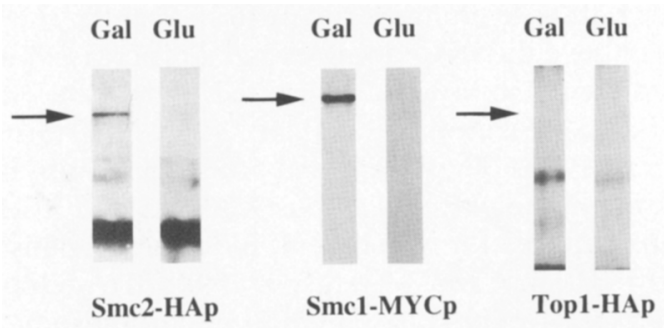

Figure 4. Coimmunoprecipitation of Trf4p, Smclp, and Smc2p. A strain containing a $\triangle$ trf4-101::HIS3 null allele, was cotransformed with 2 plasmids: $p G A L 1:: T R F 4-P Y$ (pCB787) and a $2 \mu$ plasmid that expresses either SMC1-MYC (pAS258), SMC2-HA (pAS428) or TOP1-HA (pCB119). The strains were grown in either glucose- or galactose-containing medium. Protein extracts were immunoprecipitated with anti-PY antibody coupled to protein G-Sepharose beads and the precipitated material was loaded on an SDS/PAGE gel and transferred to nitrocellulose. The blots were probed with anti-MYC antibodies to detect Smcl-MYCp or anti-HA antibodies to detect the presence of Smc2-HAp or Top1-HAp. al. 1995) was introduced into a trf4 null mutant, as was a second plasmid carrying a galactose-inducible TRF4 gene tagged with a polyoma epitope (PY; Grussenmeyer et al. 1985). Extracts were prepared from the strain grown either on glucose or galactose, and the Trf4-PY protein was immunoprecipitated with an anti-PY monoclonal antibody coupled to protein G-Sepharose beads (Harlow and Lane 1988). Immunoprecipitation of Trf4-PY using $\alpha$-PY antibodies from extracts of strains grown on galactose results in coimmunoprecipitation of both SmclMYCp and Smc2-HAp, as revealed by Western analysis of immunoprecipitates (Fig. 4). In contrast, immunoprecipitation from extracts of the same strain grown in glucose, a condition under which Trf4-PY is not expressed, does not result in coimmunoprecipitation of Smc2-HAp or Smc1-MYCp (Fig. 4). No coimmunoprecipitation of Trf4-PY and Top1-HAp is observed under these conditions. Thus, Trf $4 p$ is physically associated with Smclp and Smc2p, but not with Toplp in vivo.

\section{TOP1-TRF4 function is required for the formation and maintenance of mitotic chromosome condensation in the rDNA}

A genetic interaction between an smc1-2 and a $\operatorname{trf} 4 \mathrm{mu}-$ tation and a physical interaction between the Smcl, Smc2, and Trf4 proteins suggested that the top1 trf4-ts mutant might be defective in the process of mitotic chromosome condensation. Therefore, we used a fluoresence in situ hybridization (FISH) assay (Guacci et al. 1994) to examine mitotic chromosome condensation in the top1 trf4-ts mutant directly. In this assay, cell walls are removed by enzymatic digestion and spheroplasts are adhered to a glass slide and fixed. Biotinylated DNA probes are then hybridized in situ to the nuclei and visualized using labeled avidin to examine chromosome structure (Guacci et al. 1994). The most dramatic changes in chromosome structure during the cell cycle are seen using rDNA probes (Guacci et al. 1994), presumably because of the large size of the array. Using this assay, wild-type cells arrested in $G_{1}$ display a large amorphous fluorescent signal on the edge of the chromosomal mass that is similar to the pattern obtained after staining for nucleolar proteins. In contrast, cells arrested in $\mathrm{G}_{2} / \mathrm{M}$ show intense discrete line-like fluorescent signals (Guacci et al. 1994). Figure 5A shows the difference in structure of rDNA at $G_{1}\left(\alpha\right.$-factor block) versus $G_{2} / M(1.5 \mathrm{hr}$ after release from the block) in our wild-type strain. rDNA at $G_{1}$ appears as a dispersed signal on the edge of the nucleus. We have termed this nuclear appearance a puff. In contrast, at $\mathrm{G}_{2} / \mathrm{M} 60 \%$ of nuclei contain rDNA that appears to be more compact and string-like (Fig. 5A). We have termed these nuclei strings. Even at $G_{2} / M$, only about $60 \%$ of nuclei appear to contain strings in our wild-type strain (Fig. 5A and Table 4). This may indicate that the fixation procedure results in a partial disruption of the condensed state or that the cultures were not synchronized perfectly. These results are consistent with the cell-cycle-dependent changes in rDNA structure reported previously (Guacci et al. 1994). 
A

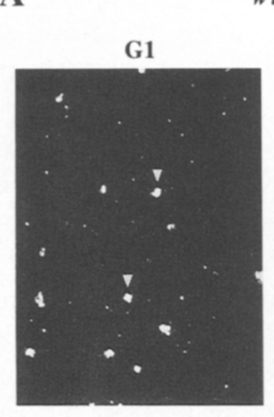

wild-type

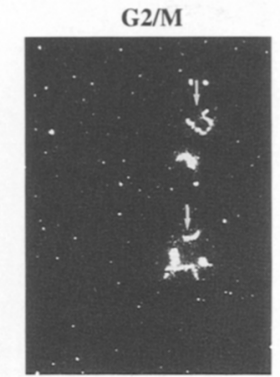

B

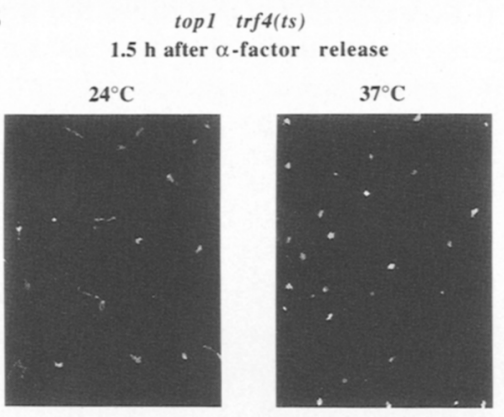

C

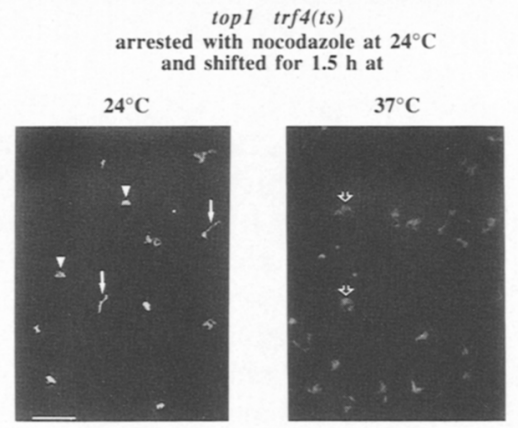

Figure 5. rDNA chromosome condensation in wild-type and the top 1 trf4-ts mutant. Cultures of wild-type (CY143) and top1 trf4-ts (CY950) strains were synchronized with $\alpha$-factor and released at either $24^{\circ} \mathrm{C}$ or $37^{\circ} \mathrm{C}$, and samples were withdrawn 1.5 $\mathrm{hr}$ after release, fixed, and spheroplasted. Nuclei were adhered to glass slides and hybridized with a biotinylated rDNA probe. (A) rDNA at different stages of the cell cycle in the wild-type strain immediately after release from $\alpha$-factor $\left(\mathrm{G}_{1}\right)$ or $1.5 \mathrm{hr}$ after release at $37^{\circ} \mathrm{C}\left(\mathrm{G}_{2} / \mathrm{M}\right)$. Arrowheads at left point to the amorphous fluorescent signals characteristic of cells in the $G_{1}$ phase of the cell cycle which we term puffs; small arrows at right show the more condensed, line-like signal (strings) that appear at the time of mitosis. $(B)$ rDNA structure $1.5 \mathrm{hr}$ after release from $\alpha$-factor at either $24^{\circ} \mathrm{C}$ or $37^{\circ} \mathrm{C}$ in the top 1 trf4-ts mutant. (C) Cells were arrested with $20 \mu \mathrm{g} / \mathrm{ml}$ of nocodazole at $24^{\circ} \mathrm{C}$ and, while arrested, half of the culture was shifted to $37^{\circ} \mathrm{C}$ and half was kept at $24^{\circ} \mathrm{C}$ for an additional $1.5 \mathrm{hr}$. Triangular arrowheads at left denote the uncondensed chromatin (puffs) and small arrows denote the condensed state (strings); arrows at right panel show partially decondensed nuclei that are observed at $37^{\circ} \mathrm{C}$. Bar, $5 \mu \mathrm{m}$.

Synchronous cultures of a top1 trf4-ts double mutant generated using $\alpha$-factor block and release were exam-
Table 4. Failure to condense rDNA in the top 1 trf4-ts mutant

\begin{tabular}{|c|c|c|c|}
\hline Strain & Temperature & $\begin{array}{c}\text { "strings" } \\
|\%|\end{array}$ & $\begin{array}{c}\text { "puffs" } \\
(\%)\end{array}$ \\
\hline Wild-type & $24^{\circ} \mathrm{C}$ & 65 & 35 \\
\hline Wild-type & $37^{\circ} \mathrm{C}$ & 57 & 42 \\
\hline Atrf4-101::HIS3 & $24^{\circ} \mathrm{C}$ & 30 & 69 \\
\hline Atrf4-101::HIS3 & $37^{\circ} \mathrm{C}$ & 33 & 66 \\
\hline$\Delta$ top1-7::LEU2 & $24^{\circ} \mathrm{C}$ & 38 & 61 \\
\hline$\Delta$ top1-7::LEU2 & $37^{\circ} \mathrm{C}$ & 31 & 67 \\
\hline$\Delta$ top 1-7::LEU2 trf4-ts & $24^{\circ} \mathrm{C}$ & 37 & 63 \\
\hline$\Delta$ top1-7::LEU2 trf4-ts & $37^{\circ} \mathrm{C}$ & 0.5 & 99 \\
\hline
\end{tabular}

Cells of wild-type (CY143), $\Delta$ top1-7:LEU2 (CY920), $\Delta$ trf4101::H153 (CY890), and $\Delta$ top1-7::LEU2 trf4-ts (CY950) were synchronized with $\alpha$-factor and released at $24^{\circ} \mathrm{C}$ or $37^{\circ} \mathrm{C}$. Samples were taken $1.5 \mathrm{hr}$ after release and examined by FISH to assay chromosome condensation as described in Materials and Methods. Slides were viewed under the microscope and counted ( $n>150$ for each strain and condition). A "puff" is a large amorphous signal that is on the edge of the nucleus characteristic of the uncondensed chromatin of cells in the $G_{1}$ phase of the cell cycle; a "string" is the more condensed, line-like fluorescent signal that is observed in the $G_{2} / M$ phase of the cell cycle.

ined for rDNA structure using the FISH assay. After 1.5 hr at $24^{\circ} \mathrm{C}, 37 \%$ of the cells from the top 1 trf4-ts culture contained rDNA in the condensed or string state and $63 \%$ contained puff nuclei (Fig. 5B), a slight (twofold) reduction in the number of condensed nuclei compared with wild-type cultures. In contrast, the $37^{\circ} \mathrm{C}$ top 1 trf4-ts culture almost completely failed to form string nuclei, with $>99 \%$ of nuclei remaining as puffs (Fig. 5B). Further incubation of the $37^{\circ} \mathrm{C}$ cultures for up to $2.5 \mathrm{hr}$ after $\alpha$-factor block/release resulted in no increase in the fraction of string nuclei (data not shown). Cultures of top1 or trf4 single mutants showed a twofold reduction in the number of nuclei with condensed rDNA compared with wild-type at either temperature (Table 4), but were clearly able to form condensed structures. Thus, the top 1 trf4-ts double mutant is unable to condense rDNA at the time of mitosis.

To determine whether TOP1-TRF4 function is required not only to establish but also to maintain condensed rDNA chromatin, we arrested cultures of the top1 trf4-ts mutant with nocodazole at $24^{\circ} \mathrm{C}$, a point at which rDNA condensation has already occurred (Guacci et al. 1994), and then shifted the cells to either $24^{\circ} \mathrm{C}$ or $37^{\circ} \mathrm{C}$ in the continued presence of nocodazole. The arrested top 1 trf $4-$ ts culture at $24^{\circ} \mathrm{C}$ contained the expected $38 \%$ of nuclei with condensed rDNA and, after $1.5 \mathrm{hr}$ of further incubation at $24^{\circ} \mathrm{C}$ in the presence of nocodazole, $95 \%$ of the condensed nuclei remained condensed (Fig. $5 \mathrm{C}$ and Table 5). In contrast, for cells shifted to $37^{\circ} \mathrm{C}$, only $35 \%$ of the original condensed nuclei remained condensed (Fig. 5C and Table 5), indicating that the majority of condensed nuclei underwent decondensation within $1.5 \mathrm{hr}$ at the restrictive temperature. In addition, what appear to be partially decondensed nuclei were observed 
Table 5. Percent of "strings" and "puffs" after nocodazole arrest at $24^{\circ} \mathrm{C}$ in topl trf4-ts

\begin{tabular}{lc}
\hline Treatment & $\begin{array}{c}\text { Original "strings" } \\
\text { remaining after } 1.5 \mathrm{hr}(\%)\end{array}$ \\
\hline $24^{\circ} \mathrm{C}+$ nocodazole & 95 \\
$37^{\circ} \mathrm{C}+$ nocodazole & 35 \\
\hline
\end{tabular}

Strain CY950 (top1 trf4-ts) was grown to logarithmic phase and nocodazole was added to a final concentration of $20 \mu \mathrm{g} / \mathrm{ml}$. After $3 \mathrm{hr}$ of incubation, half of the culture was shifted to $37^{\circ} \mathrm{C}$ in the presence of nocodazole, and the other half was kept at $24^{\circ} \mathrm{C}$ in the presence of nocodazole. After $1.5 \mathrm{hr}$, cells were prepared for FISH and counted under the microscope to determine the percentage of "puffs" and "strings" under each condition. $n>$ 150 for each condition.

at $37^{\circ} \mathrm{C}$ (see large arrows in Fig. $5 \mathrm{C}$ ). This indicates that TOP1-TRF4 function is required both to establish and to maintain rDNA condensation at mitosis, suggesting that these proteins may play a direct role in the condensation process.

The defect in the topl trf4-ts mutant is sensed by the spindle assembly checkpoint

Recent results suggest that chromosome structure plays a more direct role than previously appreciated in formation and function of the mitotic spindle / $\mathrm{Li}$ and Nicklas 1995). The spindle assembly checkpoint genes, MAD1-3 and $B U B 1-3$, detect spindle malformations and signal cell-cycle arrest (Hoyt et al. 1991; Li and Murray 1991; Murray 1995). To determine whether the failure of mitotic chromosome condensation in a top1 trf4-ts mutant is detected by this checkpoint system, we introduced a mutation in MAD1 into the top1 trf4-ts double mutant. The top1 trf4-ts mad1 triple mutant displays roughly 100 -fold reduced viability at a semipermissive temperature $\left(29.5^{\circ} \mathrm{C}\right)$ compared with an otherwise isogenic $M A D 1^{+}$strain (Fig. 6). In contrast, little or no change in viability is observed upon introduction of a rad9 mutation, which eliminates a checkpoint for DNA damage (Weinert and Hartwell 1988) into a top1 trf4-ts strain. This suggests that, in $S$. cerevisiae, failure to condense

\begin{tabular}{|c|c|c|c|}
\hline & & $24^{\circ} \mathrm{C}$ & $29.5^{\circ} \mathrm{C}$ \\
\hline top1 & $\operatorname{trf} 4(t s)$ & $a p r$ & $a \%$ \\
\hline top1 & $\operatorname{trf} 4(t s) \operatorname{mad} 1$ & Dase.: & \\
\hline top 1 & $\operatorname{trf} 4(t s) \quad \operatorname{rad} 9$ & OFF: & rz: \\
\hline
\end{tabular}

Figure 6. The defect in the top 1 trf4-ts mutant is sensed by the spindle assembly checkpoint. Isogenic top1 trf4-ts (CY950),

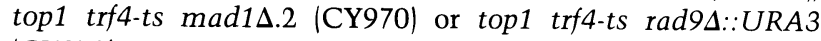
(CY978) strains were grown in YPD medium at $24^{\circ} \mathrm{C}$. The $\mathrm{A}_{600}$ was adjusted to 1.0 and serial 10 -fold dilutions were made in sterile water. $5 \mu \mathrm{l}$ of each dilution was spotted on YPD plates and incubated at either a permissive temperature $\left(24^{\circ} \mathrm{C}\right)$ or a semipermissive temperature $\left(29.5^{\circ} \mathrm{C}\right)$. chromosomes at mitosis results in an improperly formed spindle, perhaps as a result of a failure to attach microtubules to the kinetochores of uncondensed chromosomes.

We also have observed that low levels of hydroxyurea (HU), a drug that inhibits DNA synthesis, actually increases viability of the top1 trf4-ts mutant at least 10fold at a semipermissive temperature $\left(29.5^{\circ} \mathrm{C}\right.$; not shown). This phenotype is similar to mad1 mutants, which are rescued from benomyl hypersensitivity by low levels of HU (Hardwick and Murray 1995). The longer S phase that occurs in the presence of HU presumably allows more time to correctly assemble the mitotic spindle. This further suggests that DNA synthesis is not the cause of the growth defect in the top1 trf4-ts mutant, because a drug that inhibits DNA synthesis increases viability of the mutant.

\section{Discussion}

In addition to the previously recognized roles of topo I in DNA replication and rRNA transcription, we have found that topo $I$ is required, in combination with TRF4, for proper chromosome condensation at mitosis. Synchronous cultures of a top1 trf4-ts mutant display aberrant spindle elongation and nuclear division and lose viability shortly after passage through mitosis. A direct examination of mitotic chromosomes using a FISH assay indicates that the top1 trf4-ts double mutant fails to condense rDNA-containing chromosomes at the time of mitosis. Furthermore, TRF4 function is required to maintain the condensed state, because a top1 trf4-ts mutant that has already condensed rDNA at the permissive temperature undergoes significant decondensation when shifted to the restrictive temperature. It is very likely that non-rDNA chromosomes are also affected because trf4 and top1 single mutants display a centromere-mediated plasmid segregation defect, and the double mutant undergoes a grossly aberrant nuclear division. We and others are currently developing chromosome painting methods to examine chromosome condensation in single-copy regions. Immunoprecipitation experiments indicate that the Trf4 protein is physically associated with Smclp and Smc2p, the $S$. cerevisiae homologs of XCAP-C and XCAP-E, respectively. XCAP-C and $\mathrm{XCAP}-\mathrm{E}$ are Xenopus proteins required for mitotic chromosome condensation in vitro. Smc $2 p$ is also required for the maintenance of chromosome condensation in $S$. cerevisiae (Strunnikov et al. 1995). Taken together, these data indicate that TOP1 and TRF4 participate in overlapping or dependent steps in mitotic chromosome condensation and serve to define a previously unrecognized biological function for topo I.

\section{The role of topo I at mitosis}

The inviability of the top1 trf4-ts double mutant at the restrictive temperature could result from the participation of both proteins directly in mitotic chromosome condensation or from an aberrant round of DNA replication in the absence of topo I that results in the forma- 
tion of chromosomes that are poor substrates for subsequent mitotic condensation promoted by Trf4p. The aberrant round of DNA synthesis in a top1 background might result in improper nucleosome reassembly, for example, an activity that topo I can promote in in vitro assays (Almouzni and Mechali 1988; Hirano and Mitchison 1991). This explanation would predict that involvement of topo I in condensation in vitro would be observed only in a replication-coupled system and not, for example, in the replication-independent Xenopus in vitro system (Hirano and Mitchison 1994). We favor a direct role for topo I in the formation of mitotic chromosomes for the following reasons: (1) DNA replication is completed at the same rate in the top1 trf4-ts mutant at either the permissive or the restrictive temperatures; (2) growth in the presence of low levels of HU, a drug that inhibits DNA synthesis, actually enhances the viability of the top1 trf4-ts mutant at a semipermissive temperature; (3) the defect in the top1 trf4-ts mutant is not sensed by the RAD9-dependent DNA damage checkpoint, whereas, in contrast, DNA replication in a strain with a mutant histone $\mathrm{H} 4$ gene that cannot be acetylated on its amino-terminal lysine residues results in a RAD9dependent cell-cycle arrest (Megee et al. 1995); and (4) top1 single mutants display an increased rate of $C E N$ plasmid nondisjunction at $24^{\circ} \mathrm{C}$, indicating that TOP 1 is required for proper centromere-mediated segregation even in the presence of TRF4.

Topo I activity per se is required for the mitotic function of TOP1 because a mutation in the active site tyrosine (Y727F) is completely unable to complement the top1 trf4 defect (I.B. Castaño and M.F. Christman unpubl.). Thus, topo I is unlikely to be a structural component of mitotic chromosomes but rather its topoisomerase activity is required for condensation, perhaps to relieve torsional stress associated with condensation. This interpretation is consistent with the apparent lack of direct association of Toplp and Trf4p. Topo II is required for chromosome condensation in $S$. pombe (Uemura et al. 1987b) and in Xenopus extracts (Adachi et al. 1991; Hirano and Mitchison 1993; Gasser 1995). However, we have detected no genetic interaction between trf4 and top2-ts mutations under conditions where a clear interaction is observed between top 1 and top2-ts, nor does TRF4 affect the level or activity of topo II (Sadoff et al. 1995). Consistent with a model in which TRF4 function overlaps with TOP1 and not TOP2 function, antibody-blocking experiments in the Xenopus in vitro system indicate that topo II is required for a very early step in condensation (resolution of tangled strands), whereas the SMC family members XCAP-C and XCAP-E are required late in the process (actual condensation; for review, see Hirano 1995). In addition, whereas XCAP-C and $\mathrm{E}$ are tightly associated with the final condensed chromosome, topo II does not appear to be (Hirano and Mitchison 1994). Thus, it is likely that TRF4 and TOP1 function in a separate aspect of condensation from TOP2. If the role of topo II is indeed limited to the early resolution of tangled strands, and the later steps in actual condensation generate torsional stress, that stress could be relieved as easily by the action of a type I DNA topoisomerase, which makes a single-stranded break during the relaxation reaction, as by a type II DNA topoisomerase, which makes a double-stranded break.

\section{Mitotic chromosome condensation and the spindle assembly checkpoint}

Recent results suggest strongly that the primary event that activates the spindle assembly checkpoint in $S$. cerevisiae is failure to attach a microtubule to a kinetochore (Wells and Murray 1996). Data from work in mammalian systems suggests this is also true for higher cells (Rieder et al. 1994) and that a lack of tension resulting from failure of chromosomes to attach to kinetochore microtubules from both poles is what is sensed by the checkpoint (Li and Nicklas 1995). The failure to condense chromosomes at mitosis in top1 trf4-ts cells at the restrictive temperature may result in the inability of kinetochore microtubules to attach properly to kinetochores, since the MAD1-dependent checkpoint is engaged by the resulting defect. It is also possible that the kinetochore itself is not assembled correctly in the top1 trf4-ts mutant. However, we consider a defect in kinetochore assembly less likely because the top1 trf4-ts mutant is clearly defective in the condensation of noncentromeric (rDNA) chromatin. It also appears that the defect in top1 trf4-ts cells results in defective nuclear positioning with respect to the bud site. This may indicate that extra nuclear microtubules required for correct nuclear migration (Eshel et al. 1993) cannot function properly because of a defect in the intranuclear spindle that result from chromosome decondensation.

Whereas the $M A D-B U B$-dependent checkpoint is apparently engaged by the defect in top 1 trf4-ts cells maintained at the restrictive temperature, a uniform cell-cycle arrest does not result. It could be that initially kinetochore microtubule attachment is defective, which results in cell-cycle delay, but that after longer times that ability of the checkpoint itself to function is impaired by the appearance of decondensed chromosomes. Alternatively, a weak signal could be generated by the resulting defect, which is eventually overridden. Indeed, most cells with activated MAD1 or RAD9-dependent checkpoints do eventually divide (discussed in Wells and Murray 1996). smc-ts mutants exhibit a similar catastrophic mitosis that results in a nonuniform terminal arrest morphology that is $R A D$ 9-independent (Strunnikov et al. 1993), although MAD1-dependency was not tested.

\section{Association of Trf4p, Smc1p, and Smc2p}

The genetic interaction between a $\operatorname{trf} 4$ and an $s m c 1 \mathrm{mu}-$ tant suggests that both genes function in a related pathway. Further supporting this, we find that when Trf4PYp is expressed from the GAL promoter, and the Smc proteins are overexpressed from $2 \mu$ plasmids, SmclMYCp, Smc2-HAp, and Trf4-PYp can be coimmunoprecipitated. Overexpression is necessary to monitor the interaction because the Smc proteins are present in low 
abundance (Strunnikov et al. 1995) and Trf4-PYp expressed from its own promoter is not readily detected on Western blots. Nonetheless, because of the requirement for overexpression of these proteins, the physical interaction must be interpreted cautiously. The predicted structure of the SMC gene family shows that each member contains an amino-terminal NTP binding site, a long intervening coiled-coil region with a spacer region of unknown function and a carboxy-terminal putative helix-loop-helix region that may mediate DNA binding (for review, see Peterson 1994; Hirano 1995). The overall structural organization of these proteins is similar to mechanochemical motor proteins such as kinesin. It has been suggested that Smc proteins may bind to and compact DNA via ATP-dependent movement in a manner analogous to the way kinesin promotes movement along microtubules (Strunnikov et al. 1993; Peterson 1994). An alternative model is that Smc heterodimers form a coiled-coil-based filament that serves as a scaffold for condensation (Hirano 1995). Filament formation may be required to form a complete NTP-binding site because one putative NTP-binding-domain motif is found at the amino terminus (Walker A) and another (Walker B) at the carboxyl terminus. TRF4 is not related to the SMC family and it may promote an independent step in the condensation process via $\mathrm{Smclp} / \mathrm{Smc} 2 \mathrm{p}$ association or be required for assembly of the Smc complex. The very high percentage of charged residues in Trf4p $(35 \%)$ with little overall net charge (18\% acidic and $17 \%$ basic residues) is characteristic of nonhistone chromosomal proteins (Castaño et al. 1996) and may indicate that Trf4p associates directly with condensed chromatin. The XCAP proteins are also present in a complex with several other as-yet-unidentified proteins (T. Hirano, pers. comm.). Identification of the Xenopus TRF4 homolog would be useful to examine its role in an in vitro system, and, because TRF4 is highly conserved across species (Castaño et al. 1996), this should be straightforward. Whether topo I is required in the Xenopus in vitro system has not been tested (T. Hirano, pers. comm.).

The S. pombe genes cut3 and cut14 (Saka et al. 1994) are the closest known $S$. pombe homologs of $S$. cerevisiae SMC1 and SMC2, respectively, based on evolutionary comparisons (Strunnikov et al. 1995). Yanagida and colleagues have shown that the $S$. pombe genes are also required for chromosome condensation and proper nuclear division (Saka et al. 1994). Significantly, these authors also note the surprising fact that topo I overexpression is able to suppress the temperature sensitivity of a cut3-477 mutation, whereas topo II overexpression is not (Saka et al. 1994). In addition cut3-477 top1 double mutants were observed to be inviable at $36^{\circ} \mathrm{C}$ (Saka et al. 1994). This suggests that the involvement of topo I in mitotic chromosome structure may be an evolutionarily conserved function, and further supports a model in which topo I activity is involved directly in the condensation process. We have identified clear $S$. pombe and human TRF4 homologs in data-base searches /Castaño et al. 1996). The S. pombe TRF4-related gene (GenBank accession no. Z66568) was identified via the genome proj- ect and the phenotype of a mutation in this gene is not known, although, based on our results with the $S$. cerevisiae homologs, it may show a genetic interaction with cut3 or cut14 mutations. We have also isolated an $S$. cerevisiae TRF4-related gene, TRF5, in a high-copy suppression screen. Trf $5 p$ is $55 \%$ identical and $72 \%$ similar to $\operatorname{Trf} 4 \mathrm{p}$ and, like Trf4p, is homologous to the catalytically dispensable amino terminus of TOP1 (Castaño et al. 1996). The trf4 trf5 double mutant is inviable and a trf4-ts trf5 double mutant is defective in nuclear division at the restrictive temperature (Castaño et al. 1996). Thus, TRF4 is a member of an evolutionarily conserved gene family that functions in combination with TOP1 to facilitate chromosome condensation at mitosis. Identification of other proteins that interact with $\operatorname{Trf} 4 \mathrm{p}$ and the Smc proteins should yield insight into the mechanism of mitotic chromosome condensation and further understanding of this previously unrecognized biological function of topo I.

\section{Materials and methods}

Microbial techniques

Standard methods of yeast genetics were performed (Rose et al. 1990). Escherichia coli cells (strain DH5 $\alpha$ ) were transformed by electroporation (Dower et al. 1988). Small-scale plasmid DNA isolations were made by the boiling method (Holmes and Quigley 1981) or using Qiagen columns (Qiagen, Chatsworth, CA).

\section{Media and growth conditions}

Yeast strains were grown routinely in YEP or synthetic complete media lacking the appropriate supplements with a $2 \%$ final concentration of glucose (YPD or SC), or galactose (Sherman 1991). To obtain synchronously growing cultures, cells were grown in YPD at $24^{\circ} \mathrm{C}$ to an $\mathrm{A}_{600}$ of $1.5-2$. $\alpha$-factor was added to a final concentration of $25 \mu \mathrm{g} / \mathrm{ml}$ to arrest cells in $\mathrm{G}_{1}$, and cultures were incubated for $3 \mathrm{hr}$ at $24^{\circ} \mathrm{C}$. Cells were released from the block by washing with 1 volume of sterile water and resuspending in fresh YPD. Half of the culture was incubated at $24^{\circ} \mathrm{C}$, the other half at $37^{\circ} \mathrm{C}$, and aliquots were removed every 30 min. Nocodazole arrest was performed on exponentially growing cells in YPD by addition of nocodazole to a final concentration of $20 \mu \mathrm{g} / \mathrm{ml}$ (from a $10 \mu \mathrm{g} / \mathrm{ml}$ stock solution in DMSO). Cells were then incubated at either $24^{\circ} \mathrm{C}$ or $37^{\circ} \mathrm{C}$ for $3 \mathrm{hr}$.

\section{Plasmid loss assay}

Mitotic stability of $C E N$ or $2 \mu$ plasmids was measured by determining the fraction of cells in a culture that lost the plasmid when grown under selective conditions (Strunnikov et al. 1993). Cells containing either pRS316 (CEN URA3) or pYEp24 $(2 \mu$ $U R A 3)$ were grown overnight in SC-Ura at $30^{\circ} \mathrm{C}$. Cells were diluted 1:10 in fresh SC-Ura and grown for two more generations; aliquots of these cultures were then diluted in sterile water and plated for single colonies on SC medium and incubated for 2 days at $30^{\circ} \mathrm{C}$. After colonies had grown, plates were replica printed to SC-Ura and SC plates. Percent of plasmid loss is expressed as the ratio of the number of colonies that did not grow on SC-Ura to the total number of colonies formed. 
Table 6. Yeast strains

\begin{tabular}{|c|c|c|}
\hline Strain & Genotype & Source \\
\hline CY143 & MATa ade2-1 ura3-1 trp1-1 his3-11,15 leu2-3,112 rDNA::URA3 & $\begin{array}{l}\text { Laboratory } \\
\text { collection }\end{array}$ \\
\hline CY184 & MAT $\alpha$ ade2-1 ura3-1 trp1-1 his3-11,15 leu2-3,112 rDNA::ADE2 & $\begin{array}{l}\text { Sadoff et al. } \\
1995\end{array}$ \\
\hline CY185 & MAT $\alpha$ top1-7::LEU2 ade2-1 ura3-1 trp1-1 his3-11,15 leu2-3,112 rDNA::ADE2 & $\begin{array}{c}\text { Sadoff et al. } \\
1995\end{array}$ \\
\hline CY855 & MAT $\alpha$ trf4-101::HIS3 ade2-1 ura3-1 trp1-1 his3-11,15 leu2-3,112 rDNA::ADE2 & $\begin{array}{l}\text { Sadoff et al. } \\
1995\end{array}$ \\
\hline CY890 & 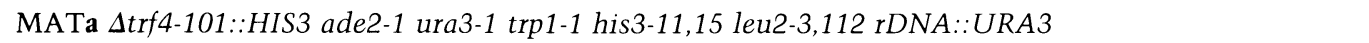 & This study \\
\hline CY920 & MATa Atop1-7::LEU2 ade2-1 ura3-1 trp1-1 his3-11,15 leu2-3,112 rDNA::ADE2 & This study \\
\hline CY923 & MAT $\alpha$ Atrf4-101::HIS3 Atop1-7::LEU2 ade2-1 ura3-1 trp1-1 his3-11,15 leu2-3,112 rDNA::ADE2/pCB432 & This study \\
\hline CY938 & MAT $\alpha$ top1-7::LEU2 trf4-ts1 ade2-1 ura3-1 trp1-1 his3-11,15 leu2-3,112 rDNA::ADE2 & This study \\
\hline CY950 & MATa $\Delta$ top1-7::LEU2 trf4-ts1 ade2-1 ura3-1 trp-1 his3-11,15 leu2-3,112 rDNA::ADE2 & This study \\
\hline CY970 & MATa $\Delta$ top1-7::LEU2 trf4-ts1 mad1A.2::URA3 ade2-1 ura3-1 trp1-1 his3-11,15 leu2-3,112 rDNA::ADE2 & This study \\
\hline CY978 & MATa Atop1-7::LEU2 trf4-ts1 rad9A::URA3 ade2-1 ura3-1 trp1-1 his3-11,15 leu2-3,112 rDNA::ADE2 & This study \\
\hline 2bAS283 & MATa ade2 his3 leu2 lys2 ura3 smc2-6 & $\begin{array}{l}\text { Strunnikov } \\
\text { et al. } 1995\end{array}$ \\
\hline $3 \mathrm{aAS} 273$ & MAT $\alpha$ ade2 his3 (leu2) lys2 ura3 smc1-2::LEU2 & $\begin{array}{l}\text { Strunnikov } \\
\text { et al. } 1995\end{array}$ \\
\hline
\end{tabular}

\section{Strain constructions}

Yeast strains are listed in Table 6. CY950: Plasmid pCB695 (trf4-ts1) integrating plasmid was partially digested with EcoRI and the linear fragment was integrated at the TRF4 locus in strain CY185 (MAT $\alpha$ top 1-7::LEU2) by selecting for $\mathrm{Ura}^{+}$at $30^{\circ} \mathrm{C}$. Integration at the TRF4 locus was confirmed by Southern analysis. Excision of the plasmid was selected for by streaking cells on plates containing $\mathrm{lmg} / \mathrm{ml} 5$-fluoro-orotic acid (5-FOA) at $24^{\circ} \mathrm{C}$. 5-FOA-resistant colonies were then screened for temperature sensitive (ts) growth at $37^{\circ} \mathrm{C}$. The resulting ts strain was named CY938. The mating type of CY938 was switched to a to generate CY950 by introducing pCB10, which contains the $H O$ gene expressed from the GAL1 promoter (Herskowitz and
Jensen 1991). After induction by growth in galactose containing medium, colonies were screened to identify a maters. CY890: Plasmid pCB470 (Sadoff et al. 1995) was digested with SacI to release a 4-kb trf4-101::HIS3 fragment that was used to disrupt the TRF4 locus in strain CY143. Disruption at the TRF4 locus was confirmed by Southern blot. This strain contains $r D N$ $A:: U R A 3$. Ura ${ }^{-}$derivatives were selected for by streaking on 5FOA plates at $30^{\circ} \mathrm{C}$ in order to create a selection for $U R A 3$ marked plasmids for immunoprecipitation studies. CY970: Plasmid pKH160 containing the mad1A.2::URA3 deletion allele (Hardwick and Murray 1995), was digested with EcoRI and HindIII, and the fragment containing this allele was used to disrupt the MAD1 locus of strain CY950. Disruption of MAD1

Table 7. Plasmids

\begin{tabular}{|c|c|c|}
\hline Plasmid & Genotype & Source \\
\hline pCB10 & $p G A L:: H O U R A 3$ CEN & Herskowitz and Jensen 1991 \\
\hline pCB119 & TOP1-HA URA3 $2 \mu$ & This study \\
\hline pCB431 & TRF4 TRP1 CEN & Sadoff et al. 1995 \\
\hline pCB432 & TRF4 URA3 CEN & Sadoff et al. 1995 \\
\hline pCB635 & TRF4 TRP1 CEN & This study \\
\hline pCB694 & trf4-ts1 R360C TRP1 CEN & This study \\
\hline pCB695 & 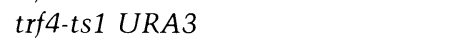 & This study \\
\hline pCB699 & TRF4-PY URA3 CEN & This study \\
\hline pCB700 & pGAL1::TRF4-PY URA3 LEU2 $2 \mu$ & This study \\
\hline pCB787 & $p G A L 1:: T R F 4-P Y$ URA3 $2 \mu$ & This study \\
\hline pRS306 & URA3 & Sikorski and Hieter 1989 \\
\hline pRS314 & TRP1 CEN & Sikorski and Hieter 1989 \\
\hline pRS316 & URA3 CEN & Sikorski and Hieter 1989 \\
\hline pYEp24 & $U R A 32 \mu$ & Lab collection \\
\hline pYEp435 & $p G A L$ vector $U R A 3$ LEU2 $2 \mu$ & Ma et al. 1987 \\
\hline pAS258 & $S M C 1-M Y C U R A 32 \mu$ & Strunnikov et al. 1995 \\
\hline pAS428 & SMC2::HA LEU2 $2 \mu$ & Strunnikov et al. 1995 \\
\hline pKH160 & $\operatorname{mad} 1 \Delta .2:: U R A 3$ & Hardwick and Murray 1995 \\
\hline pRR330 & $\operatorname{rad} 9 \Delta:: U R A 3$ & Schiestl et al. 1989 \\
\hline p632 & $r D N A$ & Keil and Roeder 1984 \\
\hline
\end{tabular}


was confirmed by Southern blot. CY987: plasmid pRR330 was digested with EcoRI and SalI and the 7.1-kb fragment containing the rad9D::URA3 allele (Schiestl et al. 1989) was used to disrupt the $R A D 9$ locus of strain CY950. Disruption of $R A D 9$ was verified by Southern blot.

\section{Plasmid constructions}

Plasmids used in this study are listed in Table 7. pCB635: A 2.1-kb PCR product containing wild-type TRF4 and 396 bp upstream from the ATG was made using primers to which BglII sites were added: 5'-GAAGATCTAATATCCTATAAAACTCAGAA-3' and 5'-GAAGATCTTCTTAAACGTATAAGGATTAT-3' using pCB431 (TRF4 TRP1 CEN; Sadoff et al. 1995) as a template. The PCR product was digested with BgIII and cloned into the BamHI site of pRS314 (Sikorski and Hieter 1989). pCB694: pCB635 was mutagenized in vitro with hydroxylamine (Rose et al. 1990). $10 \mu \mathrm{g}$ of plasmid DNA was resuspended in 1 $M$ hydroxylamine and incubated at $75^{\circ} \mathrm{C}$ for $1 \mathrm{hr}$. After gel filtration in a Sephadex G-50 spin column, transformation of $E$. coli and isolation of plasmid DNA, the pool of mutant plasmids was used to transform CY923 (trf4-101::HIS3 top1-7::LEU2/ pTRF4 URA3 CEN) by selecting for $\operatorname{Trp}^{+}$. Transformants were grown nonselectively for the pTRF4 URA3 plasmid and printed to 5-FOA plates at $24^{\circ} \mathrm{C}$ and $37^{\circ} \mathrm{C}$. Colonies that gave 5-FOA resistant segregants at $24^{\circ} \mathrm{C}$ but not at $37^{\circ} \mathrm{C}$ were retained as trf4-ts candidates. pCB694 was then recovered from one trf4-ts candidate grown at $24^{\circ} \mathrm{C}$ and it was confirmed that the trf 4 ts phenotype was plasmid-linked. The entire TRF4 gene was sequenced from pCB694 and found to contain a single $G$ to $A$ transition mutation, which results in a change of arginine 360 to cysteine (R360C or ts1). pCB695: plasmid pCB694 was digested with KpnI and NotI and the $2.1-\mathrm{kb}$ fragment containing trf4-ts1 was cloned into pRS306 previously digested with the same enzymes to create a trf4-ts1 URA3 integrating plasmid. pCB700: a PCR product containing TRF4 and two tandem copies of the polyoma epitope tag (PY; Grussenmeyer et al. 1985) at the TRF4 carboxyl terminus was synthesized using the following primers: 5 '-TCCCCCGGGGAGATCTATGGGGGCAAAGAGTG-3' and 5'-GAAGATCTTTAAAGGGTATAAGGATTTTCCATTGGCATATATTCCATTTCCATTGGCATATATTCCATATATCCATCTTCATCATC-3'. The PCR product was then digested with $B g / I I$ and cloned into the BamHI site of pYEp435 to create a pGAL1::TRF4-PY. pCB787: pCB700 was digested with KpnI and SalI and the 1.5-kb fragment containing a fragment of the LEU2 gene was removed. The ends were then made blunt using Klenow enzyme and religated.

\section{Immunoprecipitations and Western blotting}

Immunoprecipitations were performed as described /Kaffman et al. 1994), with the following modifications. Cultures were grown in SC medium lacking the relevant supplements, cells were harvested, washed, and resuspended in HSB plus protease inhibitors [45 mM HEPES-KOH (pH 7.5) $150 \mathrm{~mm} \mathrm{NaCl}, 10 \%$ glycerol, $1 \mathrm{~mm}$ EDTA, 0.5\% NP-40, 2 mм DTT, 2 mм benzamidine, $1 \mathrm{~mm}$ PMSF, leupeptin $(1 \mu \mathrm{g} / \mathrm{ml})$, pepstatin $(1 \mu \mathrm{g} / \mathrm{ml})$, antipain $(1 \mu \mathrm{g} / \mathrm{ml})$, and chymostatin $(1 \mu \mathrm{g} / \mathrm{ml})]$. Crude protein extracts were made by glass bead lysis (Kolodziej and Young 1991), and $2 \mathrm{mg}$ of total protein was incubated with $10 \mu \mathrm{l}$ of protein G-Sepharose beads that had been coupled to a monoclonal antibody against a polyoma epitope $(\alpha-\mathrm{PY})$ as described (Harlow and Lane 1988). The immunoprecipitated material was collected by centrifugation and the supernatant was recovered for later analysis. After 4 washes with 2 volumes of PBS [150 $\mathrm{mm} \mathrm{NaCl}, 10 \mathrm{~mm} \mathrm{NaPO}_{4}(\mathrm{pH} 7.4)+0.1 \%$ NP-40), the samples were resuspended in $10 \mu \mathrm{l}$ of SDS-PAGE sample buffer containing 2-mercaptoethanol and boiled for $5 \mathrm{~min}$ before loading on a $10 \%$ SDS polyacrylamide gel. Following electrophoresis, the gel was electrotransferred to nitrocellulose membranes and probed with either affinity-purified $\alpha-P Y$ monoclonal antibody from cell line AK2987 (1 to 500 dilution), $\alpha$-HA monoclonal antibody 12 CA5 (1 to 13000 dilution), or $\alpha$-MYC (9E10) monoclonal antibody (Santa Cruz Biotechnology; 1:1000 dilution); the secondary antibody used was HRP-coupled-goat antimouse IgG (Bio-Rad laboratories, Richmond CA; 1:10,000 dilution). The blots were developed with enhanced chemiluminescence reagents (Amersham).

\section{Flow cytometry}

Yeast cells were synchronized with $\alpha$-factor for $3 \mathrm{hr}$ at $24^{\circ} \mathrm{C}$, collected by centrifugation and resuspended in fresh media with no $\alpha$-factor at either $24^{\circ} \mathrm{C}$ or $37^{\circ} \mathrm{C}$. Aliquots were taken immediately after pheromone release, and every $30 \mathrm{~min}$ thereafter. Cells were fixed with $70 \%$ ethanol, treated with $0.1 \%$ RNase followed by $5 \mathrm{mg} / \mathrm{ml}$ proteinase $\mathrm{K}$ prior to staining with propidium iodide. Cells were analyzed on a Beckton Dickinson flow machine.

\section{Indirect immunofluorescence and nuclear staining}

We used adaptations of the protocols described (Pringle et al. 1991) as follows: Samples of cultures of synchronously growing cells were fixed in $3.7 \%$ para-formaldehyde with gentle shaking for $1 \mathrm{hr}$ at room temperature. Cells were then retained by filtration through a $0.2 \mu \mathrm{m}$ disposable filter and washed with 3 volumes of solution $\mathrm{B}$ [1.2 M sorbitol in $\left.100 \mathrm{mM} \mathrm{KPO}_{4}(\mathrm{pH} 7.5)\right]$. Cells were resuspended in $250 \mu \mathrm{l}$ of solution $\mathrm{B}$ and spheroplasted by treatment with lyticase. After washing, the cells were adhered to polyethylenimine-coated slides and fixed by dipping in cold methanol. Slides were incubated with a monoclonal rat antiyeast tubulin antibody (YOL1/34; 1:10 dilution, Accurate Chemical, Westbury, NY). The secondary antibody was Texas Red-conjugated donkey antirat IgG (1:50 dilution; Jackson Immunoresearch Labs, West Grove, PA). Cells were then stained with 4,6-diamidino-2-phenylindole (DAPI, $0.2 \mu \mathrm{g}$ / $\mathrm{ml}$ ) for $15 \mathrm{~min}$, washed and mounted in $0.1 \% p$-phenylenediamine in $90 \%$ glycerol and phosphate buffered saline (PBS).

\section{FISH assay for rDNA chromosome condensation}

Labeling DNA for fluorescence in situ hybridization Thirty nanograms of p632 plasmid DNA containing rDNA (Keil and Roeder 1984; Guacci et al. 1994) was digested with Sau3A. The restriction enzyme was removed by extraction with phenol:chloroform 1:1 and the DNA was precipitated with ethanol. The DNA was resupended in $5 \mu l$ water and labeled with biotindUTP using the Bionick kit (GIBCO-BRL).

Fluorescence in situ hybridization with rDNA Yeast strains were grown in the presence or absence of nocodazole or $\alpha$-factor to an $\mathrm{A}_{600}$ of 0.5. Fixation and hybridization were carried out as described (Guacci et al. 1994) with the following modifications. One milliliter of cells were fixed by the addition of $100 \mu \mathrm{l}$ of $37 \%$ formaldehyde followed by incubation for $2 \mathrm{hr}$ at room temperature. After washing twice in $1 \mathrm{ml}$ of water, cells were resuspended in $500 \mu \mathrm{l}$ of a buffer containing $1 \mathrm{M}$ sorbitol, $20 \mathrm{~mm}$ potassium phophate buffer ( $\mathrm{pH} 7.4), 45 \mathrm{~mm}$ beta-mercaptoetha$\mathrm{nol}$, and $100 \mu \mathrm{g} / \mathrm{ml}$ lyticase. After a $1 \mathrm{hr}$ incubation at $37^{\circ} \mathrm{C}, 500$ 
$\mu \mathrm{l}$ of $1 \%$ Triton was added. The spheroplasted cells were spun down and resuspended in $1 \mathrm{ml}$ of water. Cells $(20 \mu \mathrm{l})$ were dropped onto polylysine coated slides and, after $5 \mathrm{~min}$ of attachment, washed with $0.5 \%$ sodium dodecyl sulfate. Slides were fixed in methanol:acetic acid $(3: 1)$ and dried for $24 \mathrm{hr}$ at room temperature before hybridization.

Slides were treated with $100 \mu \mathrm{g} / \mathrm{ml}$ RNaseA in $2 \times \mathrm{SSC}$ (Sambrook et al. 1989) for $1 \mathrm{hr}$ at $37^{\circ} \mathrm{C}$. After dehydration in a $70 \%$, $80 \%, 95 \%, 100 \%$ ethanol wash series, slides were denatured in $2 \times$ SSC, $70 \%$ formamide $(\mathrm{pH} 7)$ at $70^{\circ} \mathrm{C}$. Slides were treated with $4 \mathrm{mAnson}$ Units/ml proteinase $\mathrm{K}$ (GIBCO-BRL) in $20 \mathrm{~mm}$ Tris/ $\mathrm{HCl}(\mathrm{pH} 7.5)$ and $2 \mathrm{mM} \mathrm{CaCl}_{2}$ for $20 \mathrm{~min}$ at $37^{\circ} \mathrm{C}$. The slides were dehydrated in an ethanol wash series as above. $1 \mu \mathrm{l}$ of biotin-labeled DNA was mixed with $1 \mu$ l of human placental DNA (Sigma Chemicals) and $5 \mu \mathrm{l}$ of $1.4 \times$ yeast hybridization mix ( $1 \mathrm{~g}$ dextrane sulfate, $5 \mathrm{ml}$ formamide, $1 \mathrm{ml} 20 \times$ SSC). The solution was denatured at $70^{\circ} \mathrm{C}$ for $10 \mathrm{~min}$ and applied to the slides. After coverslip addition, the slides were incubated in a humid chamber overnight at $30^{\circ} \mathrm{C}$.

The next day the slides were washed three times in $2 \times$ SSC, $60 \%$ formamide $(\mathrm{pH} 7)$ at $37^{\circ} \mathrm{C}$, and once in $0.1 \mathrm{M}$ sodium phosphate buffer (pH 8), $0.03 \%$ NP40 (Sigma) at room temperature. Fluorescence staining was performed by incubation with $5 \mu \mathrm{g} /$ $\mathrm{ml}$ FITC-avidin (Vector Laboratories) in $4 \times$ SSC, $0.1 \%$ Triton $\mathrm{X} 100,5 \%$ BSA for $20 \mathrm{~min}$, followed by three washes in $4 \times$ SSC, $0.1 \%$ Triton X-100 (Sigma), incubation with $5 \mu \mathrm{g} / \mathrm{ml}$ biotinylated anti-avidin (Vector Laboratories) in $4 \times$ SSC, $0.1 \%$ Triton $\mathrm{X} 100$, and $5 \%$ BSA for $20 \mathrm{~min}$, followed by three washes in $4 \times$ SSC, $0.1 \%$ Triton X-100 (Sigma), and incubation with $5 \mu \mathrm{g}$ / $\mathrm{ml}$ FITC-avidin (Vector Laboratories) in $4 \times$ SSC, $0.1 \%$ Triton $\mathrm{X} 100,5 \%$ BSA for $20 \mathrm{~min}$, followed by three washes in $4 \times$ SSC, $0.1 \%$ Triton X-100. Slides were desalted in $0.1 \times$ SSC and dehydrated in an ethanol wash series. Slides were mounted with 10 $\mu M$ DAPI in antifade solution (Johnson and Nogueira-Araiyo 1981) and viewed through a Zeiss Axioplan fluorescence microscope using a $100 \times$ objective lens.

\section{Acknowledgments}

The authors thank Doug Koshland, Alexander Strunnikov, and Vincent Guacci for strains, plasmids, and extensive advice on the FISH chromosome condensation assay. We also thank Kim Arndt, Ira Herskowitz, and Andrew Murray for strains and plasmids and Ira Herskowitz, Andrew Murray, Nikki Levin, David Pellman, and M. Mitchell Smith for critical reviews of the manuscript. We are grateful to Pragati Bakshi for help in preparing the manuscript. I.C. was supported in part by a fellowship from the Organization of American States. This work was supported by National Institutes of Health grant GM46877 to M.F.C.

The publication costs of this article were defrayed in part by payment of page charges. This article must therefore be hereby marked "advertisement" in accordance with 18 USC section 1734 solely to indicate this fact.

\section{References}

Adachi, Y., M. Luke, and U.K. Laemmli. 1991. Chromosome assembly in vitro: Topoisomerase II is required for condensation. Cell 64: 137-148.

Almouzni, G. and M. Mechali. 1988. Assembly of spaced chromatin involvement of ATP and DNA topoisomerase activity. EMBO J. 7: 4355-4365.

Brill, S.J., S. DiNardo, M.K. Voelkel, and R. Sternglanz. 1987. Need for DNA topoisomerase activity as a swivel for DNA replication for transcription of ribosomal RNA. Nature 326: 414-416.

Castaño, I.B., S. Heath-Pagliuso, B.U. Sadoff, D.J. Fitzhugh, and M.F. Christman. 1996. A novel family of $T R F$ (DNA Topoisomerase I-Related Function) genes required for proper nuclear segregation. Nucleic Acids Res. 24: 2404-2410.

DiNardo, S., K. Voelkel, and R. Sternglanz. 1984. DNA topo II mutant of Saccharomyces cerevisiae: Topoisomerase II is required for segregation of daughter molecules at the termination of DNA replication. Proc. Natl. Acad. Sci. 81:26162620.

Dower, W.J., J.F. Miller, and C.W. Ragsdale. 1988. High efficiency transformation of $\mathrm{E}$. coli by high voltage electroporation. Nucleic Acids Res. 16: 6127-6145.

Eshel, D., L.A. Urrestarazu, S. Vissers, J.-C. Jauniaux, J.C. van Vliet-Reedijk, R.J. Planta, and I.R. Gibbons. 1993. Cytoplasmic dynein is required for normal nuclear segregation in yeast. Proc. Nat1. Acad. Sci. 90: 11172-11176.

Gasser, S.M. 1995. Coiling up chromosomes. Current Biol. 5: 357-360.

Goto, T. and J.C. Wang. 1985. Cloning of yeast TOP1, the gene encoding DNA topoisomerase I, and construction of mutants defective in both DNA topoisomerase I and DNA topoisomerase II. Proc. Natl. Acad. Sci. 82: 7178-7182.

Grussenmeyer, T., K.H. Scheidtman, M.A. Hutchinson, W. Eckhart, and G. Walter. 1985. Complexes of polyoma virus medium $\mathrm{T}$ antigen and cellular proteins. Proc. Natl. Acad. Sci. 82: 7952-7954.

Guacci, V., E. Hogan, and D. Koshland. 1994. Chromosome condensation and sister chromatid pairing in budding yeast. $J$. Cell Biol. 125: 517-530.

Hardwick, K.G. and A.W. Murray. 1995. Madlp, a phosphoprotein component of the spindle assembly checkpoint in budding yeast. J. Cell Biol. 131: 709-720.

Harlow, E. and D. Lane. 1988. Antibodies: A laboratory manual. Cold Spring Harbor Laboratory, Cold Spring Harbor, NY.

Herskowitz, I. and R.E. Jensen. 1991. Putting the HO gene to work. Methods Enzymol. 194: 132-146.

Hirano, T. 1995. Biochemical and genetic dissection of mitotic chromosome condensation. Trends Biochem. Sci. 20: 357361.

Hirano, T. and T.J. Mitchison. 1991. Cell cycle of control of higher-order chromatin assembly around naked DNA in vitro. J. Cell Biol. 115: 1479-1489.

- 1993. Topoisomerase II does not play a scaffolding role in the organization of mitotic chromosomes assembled in Xenopus egg extracts. I. Cell Biol. 120: 601-612.

- 1994. A heterodimeric coiled-coil protein required for mitotic chromosome condensation in vitro. Cell 79: 449458.

Holm, C., T. Goto, J.C. Wang, and D. Botstein. 1985. DNA topoisomerase II is required at the time of mitosis in yeast. Cell 41: 553-563.

Holmes, D.S. and M. Quigley. 1981. A rapid boiling method for the preparation of bacterial plasmids. Anal. Biochem. 114: 193-197.

Hoyt, M.A., L. Trotis, and B.T. Roberts. 1991. S. cerevisiae genes required for cell cycle arrest in response to loss of microtuble function. Cell 66: 507-517.

Johnson, G.D. and G.M. Nogueira-Araiyo. 1981. A simple method of reducing the fading of immunofluorescence during microscopy. J. Immunol. Methods 43: 349-350.

Kaffman, A., I. Herskowitz, R. Tjiaiı, and E.K. O'Shea. 1994. Phosphorylation of the transcription factor $\mathrm{PHO} 4$ by a cyclin-CDK complex, PHO80-PHO85. Science 263: 1153- 
1156.

Keil, R. and G.S. Roeder. 1984. Cis-acting recombination stimulating activity in a fragment of the ribosomal DNA of S. cerevisiae. Cell 39: 377-386.

Kim, R.A. and J.C. Wang. 1989. Function of DNA topoisomerases as replication swivels in Saccharomyces cerevisiae. J. Mol. Biol. 208: 257-267.

Kolodziej, P.A. and R.A. Young. 1991. Epitope tagging and protein surveillance. Methods Enzymol. 194: 508-519.

Li, R. and A.W. Murray. 1991. Feedback control of mitosis in budding yeast. Cell 66: 519-531

Li, X. and R.B. Nicklas. 1995. Mitotic forces control a cell-cycle checkpoint. Nature 373: 630-632.

Liu, L.F. and J.C. Wang. 1987. Supercoiling of the DNA template during transcription. Proc. Natl. Acad. Sci. 84: 7024-7027.

Ma, H., S. Kunes, P.J. Schatz, and D. Botstein. 1987. Plasmid construction by homologous recombination in yeast. Gene 58: 201-216.

Megee, P.C., B.A. Morgan, and M.M. Smith. 1995. Histone H4 and the maintenance of genome integrity. Genes \& Dev. 9: 1716-1727.

Murray, A.W. 1995. The genetics of cell cycle checkpoints. Curr. Opin. Genet. Dev. 5: 5-11.

Peterson, C.L. 1994. The SMC family: Novel motor proteins for chromosome condensation? Cell 79: 389-392.

Pringle, J.R., A.E. Adams, D.G. Drubin, and B.K. Haaser. 1991. Immunofluorescence methods for yeast. Methods Enzymol. 194: 565-602.

Rieder, C.L., A. Schultz, R. Cole, and G. Sluder. 1994. Anaphase onset in vertebrate somatic cells is controlled by a checkpoint that monitors sister kinetochore attachment to the spindle. J. Cell Biol. 127: 1301-1310.

Rose, M.D., F. Winston, and P. Hieter. 1990. Methods in yeast genetics: A laboratory manual. Cold Spring Harbor Laboratory Press, Cold Spring Harbor, NY.

Sadoff, B.U., S. Heath-Pagliuso, I.B. Castaño, Y. Zhu, F.S. Kieff, and M.F. Christman. 1995. Isolation of mutants of Saccharomyces cerevisiae requiring DNA topoisomerase I. Genetics 141: 465-479.

Saka, Y., T. Sutani, Y. Yamashita, S. Saitoh, M. Takeuchi, Y. Nakaseko, and M. Yanagida. 1994. Fission yeast cut3 and cut 14 , members of a ubiquitous protein family, are required for chromosome condensation and segregation in mitosis. EMBO I. 13: 4938-4952.

Sambrook, J., E.F. Fritsch, and T. Maniatis. 1989. Molecular cloning: A laboratory manual. Cold Spring Harbor Laboratory Press, Cold Spring Harbor, NY.

Schiestl, R.H., P. Reynolds, S. Prakash, and L. Prakash. 1989. Cloning and sequence analysis of the Saccharomyces cerevisiae RAD9 gene and further evidence that its product is required for cell cycle arrest induced by DNA damage. Mol. Cell. Biol. 9: 1882-1896.

Sherman, F. 1991. Getting started with yeast. In Methods in enzymology (ed. C. Guthrie and G.R. Fink), Vol. 194, pp. 3-21. Academic Press, San Diego, CA.

Sikorski, R.S. and P. Hieter. 1989. A system of shuttle vectors and yeast host strains designed for efficient manipulation of DNA in Saccharomyces cerevisiae. Genetics 122: 19-27.

Strunnikov, A.V., V.L. Larionov, and D. Koshland. 1993. SMC1: An essential yeast gene encoding a putative head-rod-tail protein is required for nuclear division and defines a new ubiquitous protein family. J. Cell Biol. 123: 1635-1648.

Strunnikov, A.V., E. Hogan, and D. Koshland. 1995. SMC2 a Saccharomyces cerevisiae gene essential for chromosome segregation and condensation, defines a subgroup within the SMC family. Genes \& Dev. 9: 587-599.
Thrash, C., K. Voelkel, S. DiNardo, and R. Sternglanz. 1984. Identification of Saccharomyces cerevisiae mutants deficient in DNA topoisomerase I activity. I. Biol. Chem. 259: 1375-1377.

Thrash, C., A.T. Bankier, B.G. Barrell, and R. Sternglanz. 1985. Cloning, characterization, and sequence of the yeast DNA topoisomerase I gene. Proc. Natl. Acad. Sci. 82: 4374-4378.

Uemura, T. and M. Yanagida. 1984. Isolation of type I and II DNA topoisomerase mutants from fission yeast: Single and double mutants show different phenotypes in cell growth and chromatin organization. EMBO J. 3: 1737-1744.

Uemura, T., K. Morino, S. Uzawa, K. Shiozaki, and M. Yanagida. 1987a. Cloning and sequencing of Schizosaccharomyces pombe DNA topoisomerase I gene, and effect of gene disruption. Nucleic Acids Res. 15: 9727-9739.

Uemura, T., H. Ohkura, Y. Adachi, K. Morino, K. Shiozaki, and M. Yanagida. 1987b. DNA topoisomerase II is required for condensation and separation of mitotic chromosomes in S. pombe. Cell 50: 917-925.

Wang, J.C. and A.S. Lynch. 1993. Transcription and DNA supercoiling. Curr. Opin. Genet. Dev. 5: 764-768.

Weinert, T.A. and L.H. Hartwell. 1988. The RAD9 gene controls the cell cycle response to DNA damage in Saccharomyces cerevisiae. Science 241: 317-322.

Wells, W.A.E. and A. Murray. 1996. Aberrant segregating centromeres activate the spindle assembly checkpoint in budding yeast. J. Cell Biol. 133: 75-84.

Zhu, Y., C.L. Peterson, and M.F. Christman. 1995. HPR1 encodes a global positive regulator of transcription in Saccharomyces cerevisiae. Mol. Cell. Biol. 15: 1698-1708. 


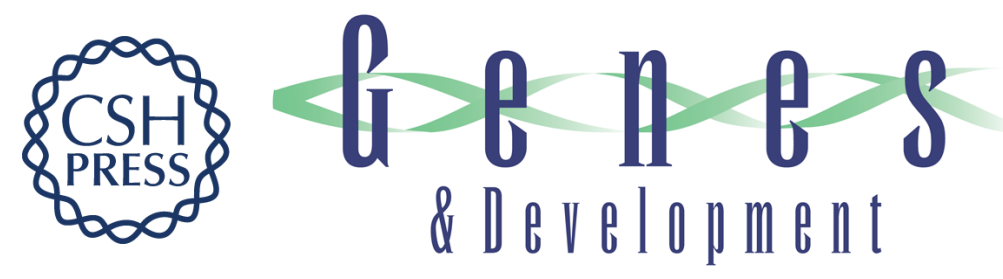

\section{Mitotic chromosome condensation in the rDNA requires TRF4 and DNA topoisomerase I in Saccharomyces cerevisiae.}

I B Castaño, P M Brzoska, B U Sadoff, et al.

Genes Dev. 1996, 10:

Access the most recent version at doi:10.1101/gad.10.20.2564

References

This article cites 49 articles, 21 of which can be accessed free at:

http://genesdev.cshlp.org/content/10/20/2564.full.html\#ref-list-1

License

Email Alerting

Receive free email alerts when new articles cite this article - sign up in the box at the top

Service right corner of the article or click here.

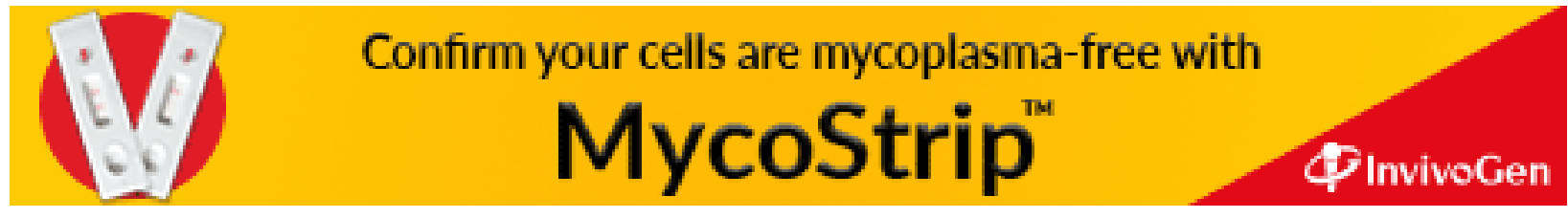

